$\underline{\text { Short Report }}$

\title{
Jatrowediol, a Lathyrane Diterpene from Jatropha weddelliana
}

\author{
Rosenei L. Brum ${ }^{a *}$, Alberto J. Cavalheiro ${ }^{b}$, Franco D. Monache ${ }^{c}$ and Ivo Vencato ${ }^{d}$ \\ ${ }^{\mathrm{a}}$ Departamento de Química / CCET, Universidade Federal de Mato Grosso do Sul, \\ C. P. 549, 79070-900 Campo Grande - MS, Brazil \\ ${ }^{\mathrm{b}}$ Instituto de Química, Universidade Estadual Paulista de Araraquara, 14801-970 Araraquara - SP, Brazil \\ ${ }^{c}$ Centro Chimica dei Recettori del C. N. R., Istituto di Chimica, U.C.S.C., Largo Francesco Vito 1, 00168, Roma, Italy \\ ${ }^{\mathrm{d}}$ Departamento de Física, Universidade Federal de Goiás, 74001-970 Goiânia - GO, Brazil
}

\begin{abstract}
A partir das raízes de Jatropha weddelliana foram isolados os diterpenóides jatrogrossidiona, 4Z-jatrogrossidentadiona, 15-epi-4Z-jatrogrossidentadiona, 4E-jatrogrossidentadiona,15-epi-4Ejatrogrossidentadiona, 2-hidroxiisojatrogrossidiona, 2-epi-hidroxiisojatrogrossidiona e jatrowediol. A elucidação da estrutura do jatrowediol, um novo diterpenóide latirânico, foi realizada por meio de análises por técnicas de RMN e de difração de raios-X.

Jatrogrossidion, 4Z-jatrogrossidentadion, 15-epi-4Z-jatrogrossidentadion, 4Ejatrogrossidentadion, 15-epi-4E-jatrogrossidentadion, 2-hydroxyisojatrogrossidion, 2-epihydroxyisojatrogrossidion and jatrowediol have been isolated from the stems of Jatropha weddelliana. The elucidation of the structure of the latter, a novel lathyrane, was accomplished by detailed NMR investigation and X-ray diffraction analysis.
\end{abstract}

Keywords: Jatropha weddelliana, Euphorbiaceae, diterpene, lathyrane, jatrowediol, Pantanal, $\mathrm{X}$-ray diffraction analysis

\section{Introduction}

Jatropha weddelliana is a shrub found in calcimorphic and dry soils of the highlands of the bearing the pantanal of Mato Grosso do Sul, Brazil ${ }^{1}$.

In this work we describe the chemical studies with the dichloromethane extract of the stems of $J$. weddelliana, that yielded a novel lathyrane diterpene, jatrowediol (1), and other seven known diterpenes: jatrogrossidion $(\mathbf{2})^{2}, 4 Z$ jatrogrossidentadion $(\mathbf{3})^{2}, 15$-epi-4Z-jatrogrossidentadion $(\mathbf{4})^{2}$, $4 E$-jatrogrossidentadion $(\mathbf{5})^{2}, 15$-epi-4E-jatrogrossiden-tadion $(6)^{2,3}$, 2-hydroxyisojatrogrossidion $(7)^{2}$, and 2-epihydroxyisojatrogrossidion $(\mathbf{8})^{2}$.

\section{Experimental}

General experimental procedures

${ }^{1} \mathrm{H},{ }^{13} \mathrm{C}$ NMR, DEPT, HETCOR, NOE and INEPT experiments: Bruker AM 300 and Varian Gemini 300

e-mail: nkhonda@nin.ufms.br spectrometers; UV spectra: Hitachi U 3000 spectrometer; FTIR spectra: BOMEN MB spectrometer; EI/MS and ES/MS Mass spectra: FISONS VG Plataform II spectrometer, $70 \mathrm{eV}$.

\section{Extraction and isolation}

The powdered stems $(2.3 \mathrm{~kg})$ were exhaustively extracted with cold hexane and $\mathrm{CH}_{2} \mathrm{Cl}_{2}$. Repeated $\mathrm{CC}$ (silica gel; hexane with increasing amounts of $\mathrm{Me}_{2} \mathrm{CO}$ ) of the $\mathrm{CH}_{2} \mathrm{Cl}_{2}$ extract (73.4 g) afforded $\mathbf{1}(166.2 \mathrm{mg}), \mathbf{2}(8.7 \mathrm{mg}), \mathbf{3}(34 \mathrm{mg}), \mathbf{4}(10 \mathrm{mg}), \mathbf{5}(16$ $\mathrm{mg}), \mathbf{6}(92 \mathrm{mg})$, a mixture of $\mathbf{7}$ and $\mathbf{8}(140 \mathrm{mg})$ and $\mathbf{8}(20.5 \mathrm{mg})$.

Jatrowediol (1): white, amorphous powder, subl. at $220{ }^{\circ} \mathrm{C} .[\alpha]_{\mathrm{D}}{ }^{20}+52.7\left(\right.$ c 2.0, $\left.\mathrm{CHCl}_{3}\right) ; \mathrm{UV}, \lambda_{\max } / \mathrm{nm}\left(\mathrm{CHCl}_{3}\right)$ : 239.5; IR $\left(v_{\max } / \mathrm{cm}^{-1}\right)$ : 3518-3407 (OH), $1716(\mathrm{C}=\mathrm{O})(\mathrm{KBr})$; $\operatorname{ESMS}(\mathrm{m} / z): 334[\mathrm{M}]^{+}(0), 333[\mathrm{M}-\mathrm{H}]^{+}(14), 335[\mathrm{M}+\mathrm{H}]^{+}$ (17.5), $357[\mathrm{M}+\mathrm{Na}]^{+}(9.0), 373[\mathrm{M}+\mathrm{K}]^{+}(8.9), 352[\mathrm{M}+$ $\left.\mathrm{H}_{2} \mathrm{O}\right]^{+}(5.7), 316\left[\mathrm{M}-\mathrm{H}_{2} \mathrm{O}\right]^{+}(17.8), 299\left[\mathrm{M}-2 \mathrm{H}_{2} \mathrm{O}+\mathrm{H}\right]^{+}$ (26); ${ }^{1} \mathrm{H}$ NMR $\left(\mathrm{C}_{5} \mathrm{D}_{5} \mathrm{~N}\right)$ and ${ }^{13} \mathrm{C} N \mathrm{NMR}\left(\mathrm{C}_{5} \mathrm{D}_{5} \mathrm{~N}\right)$ : see Table 1. Jatrogrossidion (2): colourless crystals, subl. at $230^{\circ} \mathrm{C}$. $\operatorname{ESMS}(\mathrm{m} / z): 332[\mathrm{M}]^{+}(0), 333[\mathrm{M}+\mathrm{H}]^{+}(100), 355$ $[\mathrm{M}+\mathrm{Na}]^{+}(25.3), 371[\mathrm{M}+\mathrm{K}]^{+}(18.4), 315\left[\mathrm{M}-\mathrm{H}_{2} \mathrm{O}+\mathrm{H}\right]^{+}$ (95.1), $297\left[\mathrm{M}-2 \mathrm{H}_{2} \mathrm{O}+\mathrm{H}\right]^{+}$(53.6). ${ }^{1} \mathrm{H}-$ and ${ }^{13} \mathrm{C}$ NMR data identical to the literature ${ }^{2}$. 


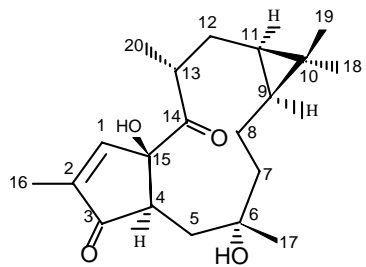

1

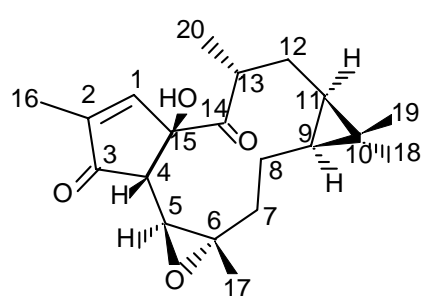

2

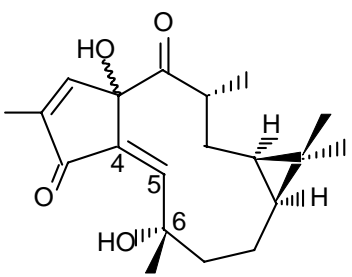

$315 \beta-\mathrm{OH}$

$415 \alpha-\mathrm{OH}$

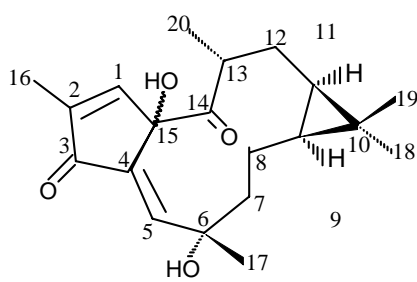

$515 \beta-\mathrm{OH}$

$615 \alpha-\mathrm{OH}$

Table 1. NMR data of $\mathbf{1}$ in $\mathrm{C}_{5} \mathrm{D}_{5} \mathrm{~N}$.

\begin{tabular}{clc}
\hline Position & $\mathrm{H}$ & $\mathrm{C}$ \\
\hline 1 & $7.34 \mathrm{~s}$ & 154.3 \\
2 & & 140.4 \\
3 & & 210.5 \\
4 & $4.16 d d(5.5 ; 2.0 \mathrm{~Hz})$ & 47.8 \\
5 & $2.62 d d(5.5 ; 14.7 \mathrm{~Hz})$ & 34.9 \\
6 & & 71.5 \\
7 & $2.07 m(7 \mathrm{a})$ and $1.79 m(7 \mathrm{~b})$ & 41.0 \\
8 & $1.45 m(8 \mathrm{a})$ and $1.23 m(8 \mathrm{~b})$ & 17.5 \\
9 & $0.33 m$ & 27.1 \\
10 & & 15.7 \\
11 & $0.79 m$ & 20.0 \\
12 & $2.50 d(14.8 \mathrm{~Hz}, 12 \mathrm{a})$ and & \\
& $1.97 d d(14.8 ; 4.8 \mathrm{~Hz}, 12 \mathrm{~b})$ & 28.2 \\
13 & $3.99 m$ & 40.3 \\
14 & & 213.3 \\
15 & $8.05 s$ & 85.9 \\
16 & $1.62 s$ & 9.9 \\
17 & $1.53 s$ & 29.0 \\
18 & $1.03 s$ & 28.9 \\
19 & $0.91 s$ & 15.1 \\
20 & $1.39 d(6.9 \mathrm{~Hz})$ & 15.4 \\
\hline
\end{tabular}

4Z-Jatrogrossidentadion (3): colourless crystals, m.p. 167-168 ${ }^{\circ} \mathrm{C}$; UV $\lambda_{\max } / \mathrm{nm}\left(\mathrm{CHCl}_{3}\right): 239$; IR $\left(v_{\max } / \mathrm{cm}^{-1}\right)$ : $3409(\mathrm{OH}), 1710,1676,1632(\mathrm{C}=\mathrm{O}, \mathrm{C}=\mathrm{C}-\mathrm{C}=\mathrm{O})(\mathrm{KBr})$; EIMS $(m / z): 332[\mathrm{M}]^{+}(0), 314\left[\mathrm{M}-\mathrm{H}_{2} \mathrm{O}\right]^{+}(3.6), 271$ (9.3), 163 (41.1), 69 (86.9), 67 (100); ${ }^{13} \mathrm{C} \mathrm{NMR}\left(\mathrm{CDCl}_{3}\right)$ : $\delta$ 153,8 (C-1), $146.7(\mathrm{C}-2), 196.4(\mathrm{C}-3), 134.6(\mathrm{C}-4), 149.0$ (C-5), 73.9 (C-6), 43.5 (C-7), 18.9 (C-8), 24.8 (C-9), 16.8 (C-10), 22.0 (C-11), 28.3 (C-12), 37,2 (C-13), 210,8 (C14), 84.1 (C-15), 10.8 (C-16), 29.0 (C-17), 28.6 (C-18), 15.4 (C-19), 19.4 (C-20). The assignments for C-1 and C5 have been revised with respect to the literature ${ }^{2}$.

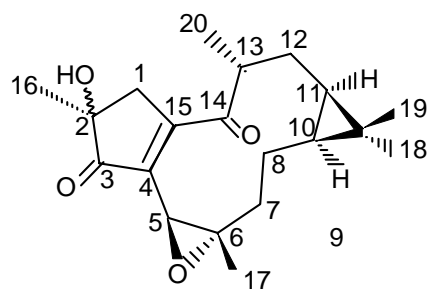

$72 \alpha-\mathrm{OH}$

$82 \beta-\mathrm{OH}$

15-epi-4Z-Jatrogrossidetadion (4): yellow solid; IR $\left(v_{\max } / \mathrm{cm}^{-1}\right): 3426(\mathrm{OH}), 1698,1653(\mathrm{C}=\mathrm{O}, \mathrm{C}=\mathrm{C}-\mathrm{C}=\mathrm{O})$ $\left(\mathrm{CHCl}_{3}\right.$ film); $\operatorname{ESMS}(\mathrm{m} / \mathrm{z}): 332[\mathrm{M}]^{+}(0), 355[\mathrm{M}+\mathrm{Na}]^{+}$ (6.7), $371[\mathrm{M}+\mathrm{K}]^{+}$(7.8), $297\left[\mathrm{M}-2 \mathrm{H}_{2} \mathrm{O}+\mathrm{H}\right]^{+}(9.5)$; ${ }^{1} \mathrm{H}$ - and ${ }^{13} \mathrm{C}$ NMR data identical to the literature ${ }^{2}$.

4-E-Jatrogrossidentadione (5): colourless crystals, m.p. $181-182^{\circ} \mathrm{C} ; \mathrm{UV} \lambda_{\max } / \mathrm{nm}\left(\mathrm{CHCl}_{3}\right): 243 ; \mathrm{IR}\left(\mathrm{v}_{\max } / \mathrm{cm}^{-1}\right)$ : $3488(\mathrm{OH}), 1709,1697,1645(\mathrm{C}=\mathrm{O}, \mathrm{C}=\mathrm{C}-\mathrm{C}=\mathrm{O})(\mathrm{KBr})$; ${ }^{13} \mathrm{C} \mathrm{NMR}\left(\mathrm{CDCl}_{3}\right): \delta 150.7(\mathrm{C}-1), 145.3(\mathrm{C}-2), 195.8(\mathrm{C}-$ 3), 132.3 (C-4), 149.0 (C-5), 73.5 (C-6), 38.7 (C-7), 18.0 (C-8), 27.4 (C-9), 17.8 (C-10), 20.0 (C-11), 29.9 (C-12), 43.6 (C-13), 213.5 (C-14), 85.1 (C-15), 10.7 (C-16), 28.6 (C-17), 29.1 (C-18), 15.0 (C-19), 16.7 (C-20). The assignements for the pairs $\mathrm{C}-2$ and C-5, C-7, C-13, Me-17 and Me-18, have been revised with respect to the literature ${ }^{2}$.

15-epi-4E-Jatrogrossidentadione (6): colourless crystals, m.p. $173-174{ }^{\circ} \mathrm{C}$; UV $\lambda_{\max } / \mathrm{nm}\left(\mathrm{CHCl}_{3}\right): 259$; $\operatorname{IR}\left(v_{\max } / \mathrm{cm}^{-1}\right)$ : $3320(\mathrm{OH}), 1722,1699,1647,1629(\mathrm{C}=\mathrm{O}$, $\mathrm{C}=\mathrm{C}-\mathrm{C}=\mathrm{O})(\mathrm{KBr}) ; \operatorname{ESMS}(\mathrm{m} / \mathrm{z}): 332[\mathrm{M}]^{+}(0), 333[\mathrm{M}+$ $\mathrm{H}]^{+}$(27.6), $355[\mathrm{M}+\mathrm{Na}]^{+}(44), 371[\mathrm{M}+\mathrm{K}]^{+}(9.8), 315$ $\left[\mathrm{M}-\mathrm{H}_{2} \mathrm{O}+\mathrm{H}\right]^{+}(100), 297\left[\mathrm{M}-2 \mathrm{H}_{2} \mathrm{O}+\mathrm{H}\right]^{+}(38.9) ;{ }^{1} \mathrm{H}-$ and ${ }^{13} \mathrm{C}$ NMR data identical to the literature ${ }^{2,3}$.

2- Hydroxyisojatrogrossidion (7): yellow solid material. $\operatorname{ESMS}(\mathrm{m} / \mathrm{z}): 332[\mathrm{M}]+$. I IR $\left(v_{\max } / \mathrm{cm}^{-1}\right): 3407(\mathrm{OH}), 1721$ $(\mathrm{C}=\mathrm{O})\left(\mathrm{CHCl}_{3}\right) ;{ }^{1} \mathrm{H}-$ and ${ }^{13} \mathrm{C}$ NMR data identical to the literature ${ }^{2}$.

2-epi-Hydroxyisojatrogrossidion (8): white, amorphous powder, m.p. $181-182^{\circ} \mathrm{C} ; \mathrm{UV} \lambda_{\max } / \mathrm{nm}\left(\mathrm{CHCl}_{3}\right): 250 ; \mathrm{IR}$ $\left(v_{\max } / \mathrm{cm}^{-1}\right): 3482(\mathrm{OH}), 1721,1698(\mathrm{C}=\mathrm{O}, \mathrm{C}=\mathrm{C}-\mathrm{C}=\mathrm{O})$ $(\mathrm{KBr}) ; \operatorname{ESMS}(\mathrm{m} / \mathrm{z}): 332[\mathrm{M}]^{+}(0), 333[\mathrm{M}+\mathrm{H}]^{+}(43.8)$, 
$315\left[\mathrm{M}-\mathrm{H}_{2} \mathrm{O}+\mathrm{H}\right]^{+}(100), 297\left[\mathrm{M}-2 \mathrm{H}_{2} \mathrm{O}+\mathrm{H}\right]^{+}(28.9)$ $355[\mathrm{M}+\mathrm{Na}]^{+}(10.9), 371[\mathrm{M}+\mathrm{K}]^{+}(6.8) ;{ }^{1} \mathrm{H}-$ and ${ }^{13} \mathrm{C}$ NMR data identical to the literature ${ }^{2}$.

\section{$X$-ray crystal structure analysis of $\mathbf{1}$}

A colourless plate single crystal $(0.50 \times 0.33 \times 0.07$ $\mathrm{mm})$ of $\mathbf{1}\left(\mathrm{C}_{20} \mathrm{H}_{30} \mathrm{O}_{4}\right)$ was mounted on an Enraf-Nonius CAD-4 diffractometer with graphite-monochromated Mo Ka radiation and $\omega-2 \theta$ scan-technique. The unit cell and the orientation matrix for the data collection were obtained by a least-squares fit of 25 centered reflections $(8.69<\theta$ $\left.<14.1^{\circ}\right)$. The intensities of three standard reflections were measured every $60 \mathrm{~min}$ and varied about $1.0 \%$ throughout the experiment. The intensity data were corrected for Lorentz and polarization effects, but not absorption corrections $\left[\mu\left(\mathrm{Mo}-\mathrm{K} \alpha=0.080 \mathrm{~mm}^{-1}\right]\right.$. The number of measured reflections was 4930 in the range $-10 \leq h \leq 10$, $9 \leq \mathrm{k} \leq 12,0 \leq 1 \leq 46$, with 3530 unique reflections, and 2529 with the condition $\mathrm{I}{ }^{3} 2 \sigma(\mathrm{I})$ were considered observed. Equivalent reflections were merged with $\mathrm{R}_{\text {int }}=3.27 \%$. Crystal data: orthorhombic, $\mathrm{P} 2{ }_{1}{ }_{1} 2_{1}$ (no.19), $a=8.833$ (2), $b=10.749(2), c=39.837(8) \mathrm{A}^{\circ}, \mathrm{Z}=8$, with two independent molecules in the asymmetric unit. The structure was solved by means of direct methods using SHELXS97 computer program ${ }^{4}$ and refined by fullmatrix least-squares techniques on $\mathrm{F}^{2}$ with SHELXL97 computer program ${ }^{5}$. H atoms were placed geometrically except those on the hydroxyl groups. The final refinement gave $\mathrm{R}$ (on $\mathrm{F}$ ) factor of 0.055 , $\mathrm{wR}\left(\mathrm{on} \mathrm{F}^{2}\right.$ ) $=0.152$ for 446 refined parameters.

\section{Results and Discussion}

Jatrowediol (1) was obtained from the dichloromethane extract of the stems of $J$. weddelliana as a dextrorotatory powder. The molecular formula $\mathrm{C}_{20} \mathrm{H}_{30} \mathrm{O}_{4}$ was deduced from the NMR data and the molecular ion $([\mathrm{M}+1]$ at $\mathrm{m} / \mathrm{z}$ 335) from the Electron Spray Mass Spectrum. The IR spectrum indicated the presence of carbonyl $\left(1716 \mathrm{~cm}^{-1}\right)$ and hydroxyl groups $\left(3495 \mathrm{~cm}^{-1}\right)$. The UV spectrum in $\mathrm{CHCl}_{3}$ afforded a $\lambda_{\text {max }}$ at $239.5 \mathrm{~nm}(-\mathrm{C}=\mathrm{C}-\mathrm{C}=\mathrm{O})$. The ${ }^{13} \mathrm{C}$ NMR and DEPT spectra presented twenty carbon signals, including characteristic signals due to a trisubstituted double bond $\left(\delta_{\mathrm{C}} 154.3\right.$ and 140.4$)$, two carbonyls $\left(\delta_{\mathrm{C}} 210.5\right.$ and 213.3), two carbinols hydroxyls $\left(\delta_{\mathrm{C}} 71.5\right.$ and 85.9), five methyls, four methylenes, four methines and a quaternary carbon. Triplets at $\delta_{\mathrm{H}} 0.34(\mathrm{t}, 1 \mathrm{H})$ and 0.79 (lt, $1 \mathrm{H})$ in the ${ }^{1} \mathrm{H}$ NMR spectrum suggested the presence of a cyclopropane moiety in the molecule. The unambiguous assignment of the protonated carbons was obtained by the
HETCOR measurements (Table 1) and decoupling experiments, while that of quaternary carbons came from the long-range HETCOR spectrum and selective INEPT experiments (Table 2). Together, the above data suggested a lathyrane gross structure for $\mathbf{1}$.

The relative stereochemistry of methyl groups and of carbons C- 6 to C- 15 was confirmed by a series of difference NOE experiments (Table 3). However, the stereochemistry of cyclopentanone ring junction with the macrocycle could not be confirmed. The signal at $\delta_{\mathrm{H}} 8.0$ could not be unambiguously assigned as refering to the hydroxyl on C-15 or on C- 6 or both. The absolute configuration of $\mathbf{1}$ was determined by single a crystal X-ray analysis (Figure 1). The two independent molecules of the asymmetric unit have the same absolute configuration.

Compounds $\mathbf{2 - 8 ^ { 2 - 3 }}$ were also isolated from the dichloromethane extract of the stems and identified by 2D NMR experiments. In particular, some assignments of the carbon signals for compounds $\mathbf{3}$ and $\mathbf{5}$ have been revised.

Table 2. Long-Range NMR connectivies of compound $\mathbf{1}$

\begin{tabular}{cccc}
\hline $\begin{array}{c}\text { Irradiated } \\
\text { proton }\end{array}$ & $\begin{array}{c}\text { Connected } \\
\text { carbons }\end{array}$ & Carbon & $\begin{array}{c}\text { Connected } \\
\text { protons }\end{array}$ \\
\hline H-1 & C2, C15, Me-16 & C-1 & Me-16 \\
H-4 & C3, C15, C6, C5 & C-2 & Me-16 \\
H-7 & C6, Me-17 & C-3 & H-1 \\
H-9 & Me-18 & C-4 & H-5 \\
H-11 & C-10 & C-5 & Me-17 \\
H-12 & C-11, Me-20 & C-6 & H-5, Me-17 \\
H-13 & C-11 & C-7 & H-5, Me-17 \\
Me-16 & C-3, C1, C2 & C-10 & Me-18, Me-19 \\
Me-17 & C6, C5 & C-15 & H-1, H-5 \\
Me-18 & C9, Me-19 & Me-17 & H-7 \\
Me-19 & C9, C10 & Me-18 & Me-19 \\
Me-20 & C-14, C-13, C-12 & & \\
\hline Selective INEPT experiments; + Long-Range HETCOR.
\end{tabular}

Table 3. NOE connectivities of compound $\mathbf{1}$

\begin{tabular}{ll}
\hline Irradiations & Connectivities \\
\hline $7.34(\mathrm{H}-1)$ & $3.99(\mathrm{H}-13), 1.62(\mathrm{Me}-16)$ \\
$1.53(\mathrm{Me}-17)$ & $2.62\left(\mathrm{H}-5_{\mathrm{a}}\right), 1.23\left(\mathrm{H}-\mathrm{f}_{\mathrm{b}}\right)$ \\
$0.91(\mathrm{Me}-19)$ & $2.51\left(\mathrm{H}-12_{\mathrm{a}}\right)$ \\
$1.03(\mathrm{Me}-18)$ & $0.34(\mathrm{H}-9), 0.79(\mathrm{H}-11)$ \\
$1.39(\mathrm{Me}-20)$ & $0.79(\mathrm{H}-11), 0.34(\mathrm{H}-9)$ \\
$0.79(\mathrm{H}-11)$ & $1.39(\mathrm{Me}-20), 0.34(\mathrm{H}-9)$ \\
$0.34(\mathrm{H}-9)$ & $1.39(\mathrm{Me}-20), 1.03(\mathrm{Me}-18), 0.79(\mathrm{H}-11)$ \\
\hline
\end{tabular}




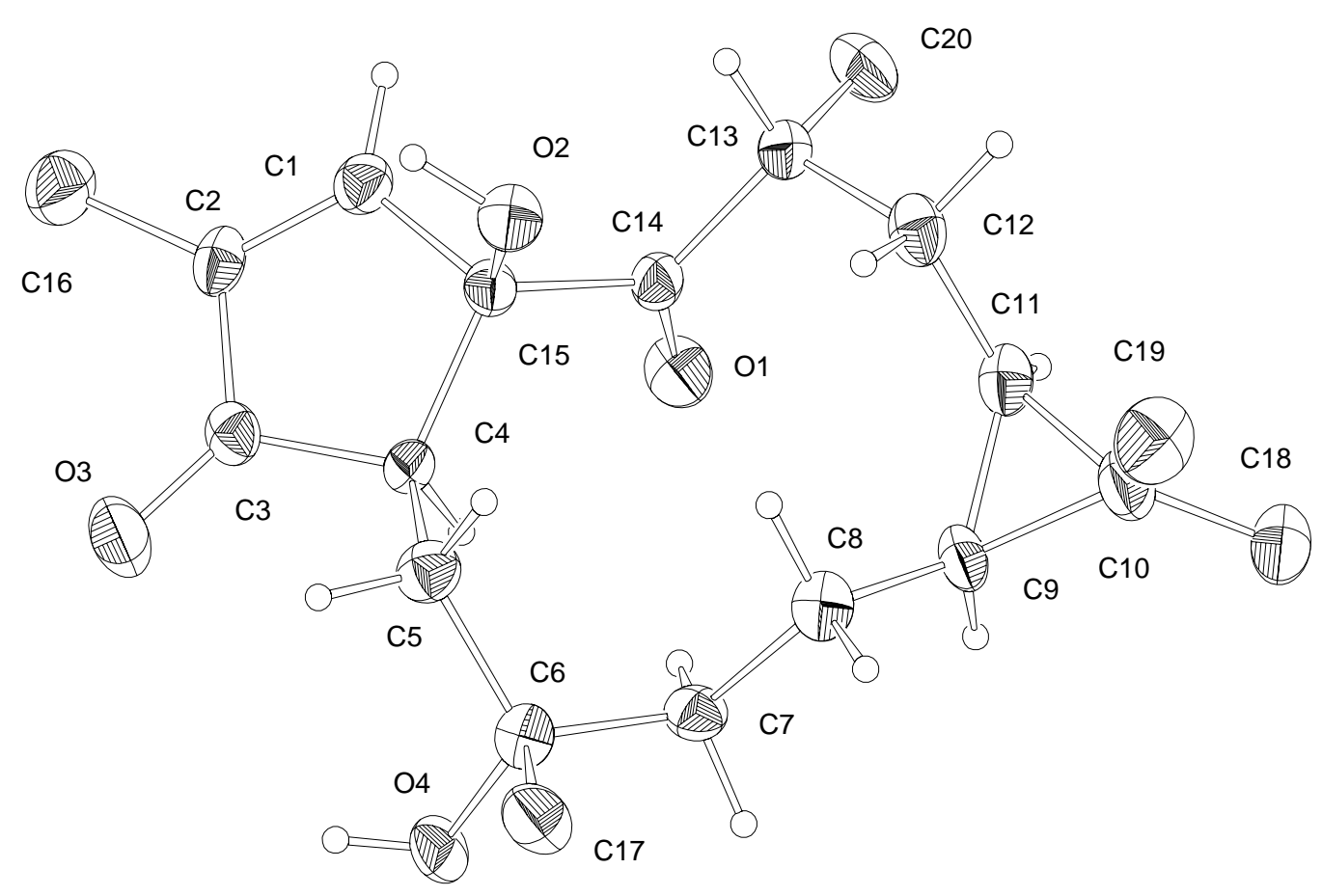

Figure 1. ZORTEP ${ }^{6}$ drawing of molecule of jatrowediol (1). The methyl H-atoms were omitted for clarity. Displacement ellipsoids are shown at the $30 \%$ probability level.

\section{Acknowledgments}

The authors are indebted to CNPq, PROPP / UFMS, PRONEX and also to the Chemistry Department of UFSC for the X-ray single crystal data collection.

\section{Supplementary Material}

Crystallographic data (excluding structure factors) for the structures in this paper have been deposited with the Cambridge Crystallographic Data Centre as supplementary publication no CCDC 15883. Copies of the data can be obtained, free of charge, on application to CCDC, 12 Union Road, Cambridge CB2 1EZ, UK, (fax: +44 1223336033 or e-mail: deposit@ccdc.cam.ac.uk).

\section{References}

1 Pott, A.; Pott, V. J. Plantas do Pantanal. EMBRAPA, Corumbá, 1994.

2. Schmeda-Hirschmann, G.; Tsichritzis, F.; Jakupovic, J. Phytochemistry 1992, 31, 1731.

3. Aiyelaagbe, O. O.; Gloer, J. B.; Adesogan, E. K.; Ekundayo, O. Fitoterapia 1998, 69, 381.

4. Sheldrick, G. M. SHELXS97. Program for the Solution of Crystal Structures. University of Göttingen, Germany, 1990.

5. Sheldrick, G. M. SHELXL97. Program for the Refinement of Crystal Structures. University of Göttingen, Germany, 1997.

6. Zsolnai, L.; Pritzkow, H. \& Huttner, G. ZORTEP. University of Heidelberg, Germany, 1996.

Received: December 09, 1999

Published on the web: February 21, 2001

FAPESP helped in meeting the publication costs of this article. 